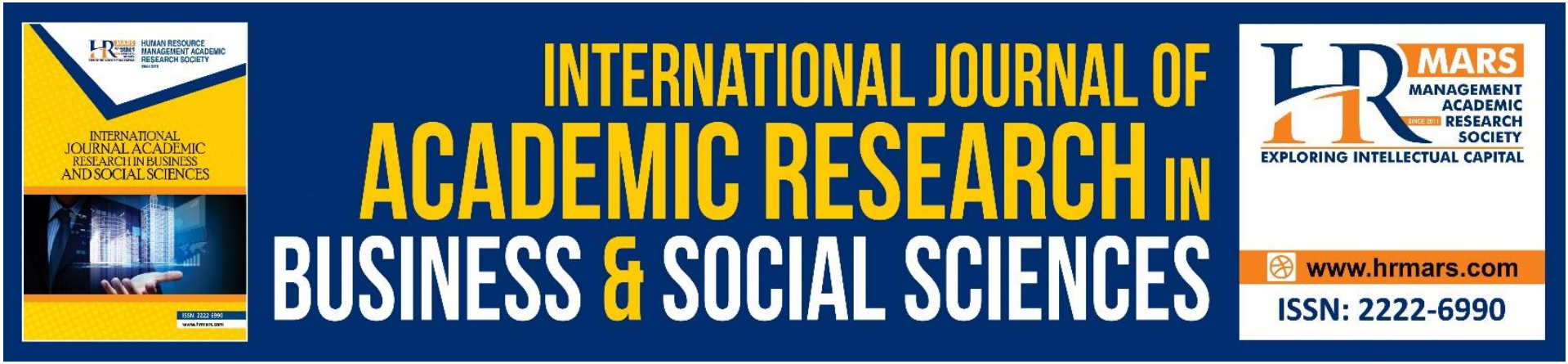

\title{
Influence of Business Management Practices on Employment Generation in Abuja
}

\author{
Mohammed Nuhu, Umaru Danladi Mohammed
}

To Link this Article: http://dx.doi.org/10.6007/IJARBSS/v11-i4/9186

DOI:10.6007/IJARBSS/v11-i4/9186

Received: 01 February 2021, Revised: 13 March 2021, Accepted: 30 March 2021

Published Online: 28 April 2021

In-Text Citation: (Nuhu \& Mohammed, 2021)

To Cite this Article: Nuhu, M., \& Mohammed, U. D. (2021). Influence of Business Management Practices on Employment Generation in Abuja. International Journal of Academic Research in Business and Social Sciences, 11(4), 1069-1082.

Copyright: @ 2021The Author(s)

Published by Human Resource Management Academic Research Society (www.hrmars.com)

This article is published under the Creative Commons Attribution (CC BY 4.0) license. Anyone may reproduce, distribute, translate and create derivative works of this article (for both commercial and non-commercial purposes), subject to full attribution to the original publication and authors. The full terms of this license may be seen at: http://creativecommons.org/licences/by/4.0/legalcode

Vol. 11, No. 4, 2021, Pg. 1069 -1082

Full Terms \& Conditions of access and use can be found athttp://hrmars.com/index.php/pages/detail/publication-ethics 


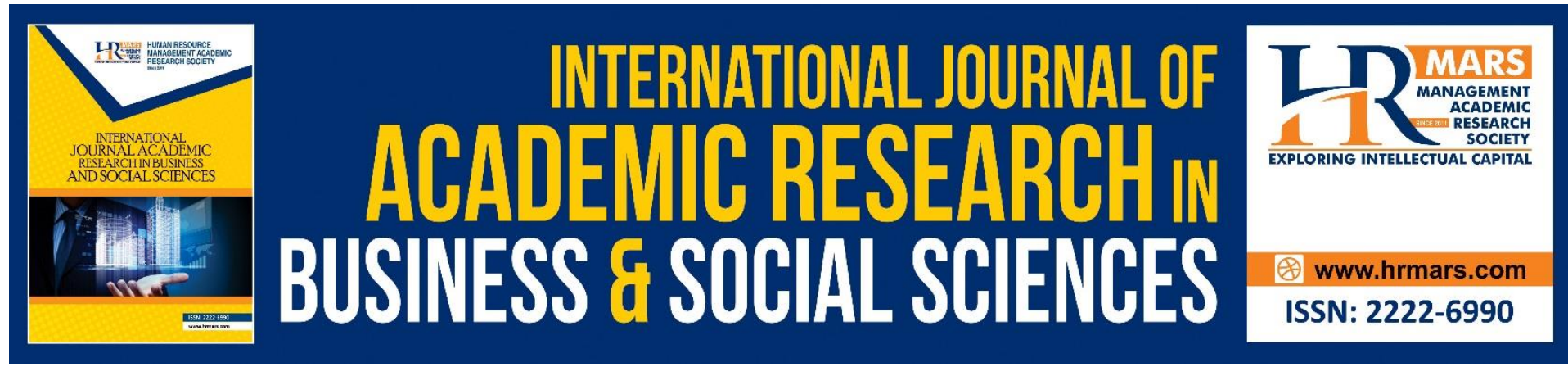

\title{
Influence of Business Management Practices on Employment Generation in Abuja
}

\author{
Mohammed Nuhu'1, Umaru Danladi Mohammed ${ }^{2}$ \\ Department of Business Management, Baze University, Abuja ${ }^{1}$ \\ Department of Business Administration, University of Abuja² \\ Email: mohammed.nuhu12@yahoo.com
}

\begin{abstract}
The issue of unemployment among graduates is alarming and the order of the day globally especially in Nigeria. Businesses address the issue through employment generation efforts which have a significant influence on the world economic growth. The main objective of the study is to investigate the influence of business management practices and employment generation in Abuja. This study adopted a survey research method which involved the use of primary survey. To test hypotheses of the study, from a population of 3,870, 363 were selected from the target population using Taro Yamani (1967) formulae. The study adopted stratified random sampling technique. Out of a total of 363 copies of a questionnaire administered, 321 copies of the questionnaire were returned out of which 11 were invalid. The valid number of 310 copies of questionnaire was used for the analysis. The study used regression analysis with the aid of SPSS software version 22 . The results also revealed that there is a positive significant influence of managerial intent on employment generation in Abuja. Also, the finding shows that there is a positive significant influence of managerial orientation on employment generation in Abuja. Hence, there is a positive significant influence of managerial perception on employment generation in Abuja. The study recommended that, the government should provide business management education programs (managerial orientation, intent, and perception) for graduates. Also, management should focus on nurturing the practical and qualities of business management. Again, government should support and assist graduates through government agencies such as NYSC to fully develop their practical skills in business management.
\end{abstract}

Keyword: Business Management Practices, Managerial Intent, Managerial Orientation, Managerial Perception, Employment Generation

\section{Introduction}

The spectacle of graduates leaving universities and other tertiary institutions without employable skills. Creating a new business is a stressful task that needs basic managerial background. Searching for wage or salary employment on the other hand is also demanding and stressful process due to the changes in the global economy and scarce job opportunities in the labour market. The crisis negatively affected labour market, in a situation where they 
were unable to accommodate the graduates from universities and institutions of higher learning (Ogundele, Akingbade, \& Akinlabi, 2017).

Nowadays, inadequate job opportunities in the labour market have resulted in the number of problems in the society, such as mental illness, loss of confidence, depression, redundancy among others (Baron \& Shane, 2015). This incidence forced individuals to find other alternative way out in order to survive. This dilemma forced wise persons among the graduates to venture into new businesses. Individual ability in adapting dynamic changes may give him/her resilience for starting a new business venture. Exploring and utilizing potential opportunities may result in creating new employment at the individual level and organizational level, which can lead to the sustainable economic development of the nations.

As a major engine of economic growth, business management accounts for the majority of new business development and job creation in the U.S. (Nuhu \& Ahmed, 2017). During the last recession in the US, while large corporations downsized millions of jobs, entrepreneurs started new companies, which helped keep unemployment at record-low levels (Baron \& Shane, 2015). Managerial activity increase employment (Kirchhoff \& Phillips, 1988), impacting the economy at the regional level (Carree \& Thurik, 2013; Acs \& Storey, 2014) and national levels (Van Stel, Carree, \& Thurik, 2015).

In Nigeria, poverty is described as a socio-economic problem that affects growth and development in the region (Nuhu \& Ahmed, 2017; Ogundele\&Olayemi, 2004). The Nigerian government has designed and embarked on several measures to reduce the degree of poverty and improve the social well-being of the people. Thus, the federal government has initiated several measures and policies to reduce the level of poverty and unemployed graduates among the masses. Business is one the measures embraced by the government to reduce mass poverty and unemployment in the country (Nuhu, Mohammed \& Ahmed, 2018; Ogundele et al, 2017). Furthermore, this gives an insight to the magnitude of this study. Abuja is the capital of Nigeria that yield a large number of graduates from across the country.

There are federal universities, state universities and private universities in Nigeria that turn out well graduates yearly that cannot be employed by the governments and private businesses in Nigeria. This unemployment saga necessitates the shift in interest to managerial development and studies to deal with the worrisome issue. These unemployment crises have affected the labour market because the employment market can't not accommodate the graduates from these universities and institutions of higher learning. Nowadays inadequate job opportunities in the labour market resulted in the number of problems in the society such as mental illness, loss of confidence, depression, redundancy among have increased.

Again, several studies on businesses management concentrated on the contribution of businesses management to sustainable economic development, job creation, innovation and resource allocation, but there is little attention paid to the effect of business management practices (managerial orientation, intent, and perception) on employment generation in Abuja. The success of any business depends on many factors such as managerial orientation, intent, perception, but these are often neglected.Therefore, this provides an important gap 
for conducting this study. Hence, this study investigates the influence of business management practices on employment generation in Abuja.

\section{Literature Review}

Business management is seen as only emerging transition economies (and it is very unequally developed in developing countries), researchers are able to observe "out-of-steady-state" phenomena and glimpse at the development of business management. From this perspective, the study of business management in Nigeria might be more revealing than if it were to be conducted in advanced industrialized countries where the development of the business has generally been more successful, is more in steady state and exhibits less variation. The next section is the reviewed of employment generation as the dependent variable in this study.

\section{Employment Generation}

Employment generation is the process of perceiving an opportunity and respond upon the opportunity. It also involves innovation, it assumed that something is created from nothing and resources are being harmonized in a new dimension. Employment generation is at the heartbeat of business management (Nuhu, Mohammed \& Ahmed, 2018). Prior research on employment generation has mentioned many antecedents that distinguish entrepreneurs from that of non- entrepreneurs.

Many scholars in the early stage of developing business management promulgated that employment generation is the heartbeat of business management (Ayoade \& Agwu, 2016). Employment generation in this study would be determined by the above variables in order to know their relationship. There are many studies that show a positive relationship between employment generation, firm survival and changes in technology (Nkechi, Ikechukwu, \& Okechukwu, 2012). This study would focus on business management practices and employment generation in Abuja.

Meanwhile, in a similar definition given by Younas and Bari, (2020) stated that employment generation stands at the nexus of lucrative opportunities and enterprising individuals. Employment generation can take many forms such as joint venture between two or more persons, or as a corporate venture, or as an independent venture managed by one or more persons acting in their own self-interest (Osabohien, Matthew, Gershon, Ogunbiyi, \& Nwosu, 2019). In the past decade, there were various studies on employment generation and different variables were used by different scholars, with the aim of finding relationship and building employment generation determinants. The next sections are reviewed of the independent variables (proxies) such as Managerial Intent, orientation and perception.

\section{Managerial Intent}

Managerial intent is defined as an individual's intention to become a job giver, not a job seeker in the near future. Intent is a state of mind directing a person's attention (and therefore experience and action) toward a specific object or a path in order to achieve something (Bird, 2019). A number of researchers have examined the concept of intention. James, Delia and Wann (2019) construed it as an independent faculty of the mind, operating through a person's attention (holding the intended image in the mind) and consent (inner 
dialog or self-talk which says, "Let it be so"). However, intent addressed the tension and showed that a person's intentions sustain value or effort despite interruptions.

Searle, Litts and Kafai (2018) have focused on processes that build or define intention, suggesting that how individuals express promises and goals is important. Since this study is concerned with individual's intent to engage in entrepreneurial behavior, which is aimed to reduce unemployment or participating any entrepreneurial activity in an existing firm (Abisuga-Oyekunle, Patra, \&Muchie, 2020; Nuhu, Mohammed \&Ahmend, 2018). They argued that intentional elements, such as expectation, attention, and belief, have on behavioral outcomes. Managerial intent is the state of mind that directs and guides the actions of the entrepreneur toward the development and the implementation of new business concepts (Khalil, Khalil, \& Khan, 2019) Personal profile such as experience, characteristics, personality and social context such as government deregulation of industries or redundancies may contribute in the formation of managerial intent (Bird, 2019).

Widiger, Sellbom, Chmielewski, Clark, Deyoung, Kotov and wright (2019) considered the decision to become an entrepreneur as voluntary and conscious. Therefore, business management may be viewed as a process that occurs over time (Zaid, Jaaron, \& Bon, 2018). In this sense, managerial intent would be a necessary step in the evolving and -sometimeslong-term process of venture creation (Searle et al, 2018). The intent to start up, then, would be a previous and a determinant element towards performing managerial behaviors (Widiger et al, 2019)

Israel and Johnmark, (2014) in their study managerial mindset among female university students of Jos, Nigeria, the researchers point out that, perception of business management, role model, and university role has significant effects on new venture creation. The study was adapted a sample size of about 400 female students from three faculties. The study analyzes the data through the means of simple percentage and transforms it into tables and charts. The study found a weak relationship between teaching businesses management and female students' managerial mindset.

In another trend of research, the study of Teixeira and Davey (2010) was conducted on 4,413 students enrolled in Portuguese higher education institutions, with the aim of determining the attitudes of higher education students to new venture creation in Portugal. The study used students' personality, (risk, creativity) managerial experience, knowledge, awareness, interest, contextual factors role models and professional experience as a determinant of managerial venture creation. The study found that students enrolled in non- universities (i.e. Polytechnics) are having more effective and potentially managerial propensities.In line with the above empirical literature reviews with many mix findings, the following hypothesis were developed:

There is no influence of business management intent on employment generation in Abuja.

\section{Managerial Orientation}

Managerial orientation is defined as an individual's attitude towards engaging in managerial activities, be it within an existing firm or creating a new venture. This attitude could be either 
favourable or unfavourable. Managerial orientation has received conceptual and empirical back up, by different authors over a period of time. Managerial orientation is one of the strategic areas of business management where scholars prioritize in developing it. This study evaluates the cumulative knowledge on the relationship between managerial orientation and employment generation. Individuals who have a managerial orientation can stand independently by applying the concept of innovation, risk- taking and proactive to the competitors positively in order to explore market opportunities. Managerial orientation creates awareness among students that can help them to set up a new enterprise after their graduation.

Managerial orientation has been examined empirically in studies that have defined this construct at the firm level. It is probable (Aburumman, Salleh, Omar, \& Abadi, 2020) that has provided a useful starting point for the concept of managerial orientation. He suggested that a management firm is one that "engages in product market innovation, undertakes somewhat risky ventures, and is first to come up with 'proactive' innovations, beating competitors to the punch".

Accordingly, he used the words "innovativeness," "risk taking," and "pro-activeness" to characterize a firm that is manageable. Later-coming researchers have adopted an approach based on Miller's (1983) original conceptualization (Aburumman et al., 2020). For example, the frequently-cited piece by Aburumman et al, (2020) investigated the managerial firms' performance in hostile and benign environments. In their study, the concept of "managerial, strategic posture" was measured using a scale that ranked firms as managerial if they were innovative, risk taking, and proactive.

More recently, Arshad, Rasli, Arshad, \& Zain, (2014) added another two characteristics to the original concept proposed by Arshad et al, (2014) autonomy and competitive aggressiveness. Autonomy refers to an individual or a team's independent action to bring forth an idea or a vision and carry it through to completion. Competitive aggressiveness refers to a firm's propensity to directly and intensely challenge and outperform industry rivals in the marketplace. Due to its "liability of newness" (Aburumman et al, 2020), many researchers (Arshad et al, (2014) argued that an aggressive stance and intense competition are critical to the survival and success of new entrants.

For the purpose of this study, managerial orientation (EO) is defined as an individual's attitude toward managerial behaviors. Compared with the managerial orientation in the mainstream business management literature, the managerial orientation in this study is distinctly different. First of all, the level of analysis is different. However, it is not true that the two EO have nothing to do with each other. The dimensions of the original EO now are presumed to predict the current EO.In line with the above empirical literature reviews with many mix findings, the following hypothesis were developed:

There is no influence of business management orientation on employment generation in Abuja.

\section{Business Management Perception}


The concept of perception combines two key elements in business management, namely, perceived feasibility and perceived desirability. Perceptions play an important role in the discovery and creation views of business management (Hennekam, Bacouel-Jentjens, \& Yang, 2020). There is a strong agreement that cognitive factors such as attitudes and perceptions towards business management has a significant role in the engagements in managerial employment(Hennekam et al, 2020). The business management perception of an individual is hardly over emphasizing due to its importance in employment generation. The business management perception is one of the issues this study would take a look into, in order to identify. Managerial perception can be defined as the perceived personal ability of an individual to discharge a given task.

Base on this notion individual can perform any activity or choose any career in line with his personal ability. In a similar study Arshad et al, (2014) argues that the choice to involve venture creation is depend of an individual characteristic and behaviors that are in line with business management perception. Self-perception theory enact that peoples come to know their own attitudes, emotions, and other internal factors partially by inferring them from observations of their own overt behavior and the circumstances on this behaviours (Teixeira and Davey 2010). Also, the author's proves that managerial behavior influences selfperception and also the activity may influence managerial perception.

Widiger et al, (2019) states that self-perception was popularized in the concept of business management by the work of (Widiger et al, 2019). The authors define self-perception as an attribution of personal competence and control which helps convert perceived failures into learning experiences. Aburumman et al, (2020) explains individual perception as a mechanism of predicting strategic risk taking through the mediating influence of self-efficacy. Individual ability and response to potential desirable opportunities has an important role to play toward shaping managerial perception.

Shapero, (1982) explains that a managerial intention totally depends on the feasibility and desirability perceptions of an individual and propensity to act. Krueger (2008) states two elements of perceived feasibility, which are perceived opportunity and availability of the resource. He opines that individuals are more likely to engage in startup activities when they are not concerned about resource problems. Therefore, business management individual perception is an important determinant of successful business ventures (Sanchez, 2013).

Shinnar, Oliver, \& Frank, (2012) in their study, managerial perception and intentions: the role of gender and culture in three countries United States, Belgium and China. The study examines how culture and gender shape managerial perceptions and intentions within Hofstede's cultural dimensions framework and gender role theory. The study tested gender differences among university students in regard to managerial perceptions across three countries. The study found significant differences in barrier perceptions. The significant relationship between barriers perceptions of business management and managerial intentions was also identified in the study. The study also discovered that culture and gender seem to play a crucial role in shaping the managerial perceptions among students. 
While other study contradicted the above, Davey, Plewa, \& Struwig (2011) conducted a study on business management perceptions and career intentions of international students. The authors selected first-year business students from three universities from different locations. Their study, they choose African countries that are either developing (Uganda and Kenya) or emerging (South Africa) and four European developed nations (Finland, Germany, Ireland, and Portugal). The study aims to distinguish managerial intentions, attitudes towards business management, role models and managerial experience between African and European students. The study also aims to lay the foundation for future comparative study between developing and developed countries in the area of graduate business management. In line with the above empirical literature reviews with many mix findings, the following hypothesis were developed:

There is no influence of business management perception on employment generation in Abuja.

\section{Theoretical Framework}

The main theoretical base of the study is theory of Planned Behavior (TPB) (1982) also refer to as Ajzen's theory (TPB) and supporting theory is Shapero's theory of business management event (SEE). There is a strong argument among the scholars on the factors that lead an individual to become an entrepreneur. Many studies used Ajzen's model theory of planned behavior in shaping managerial intention towards employment generation.

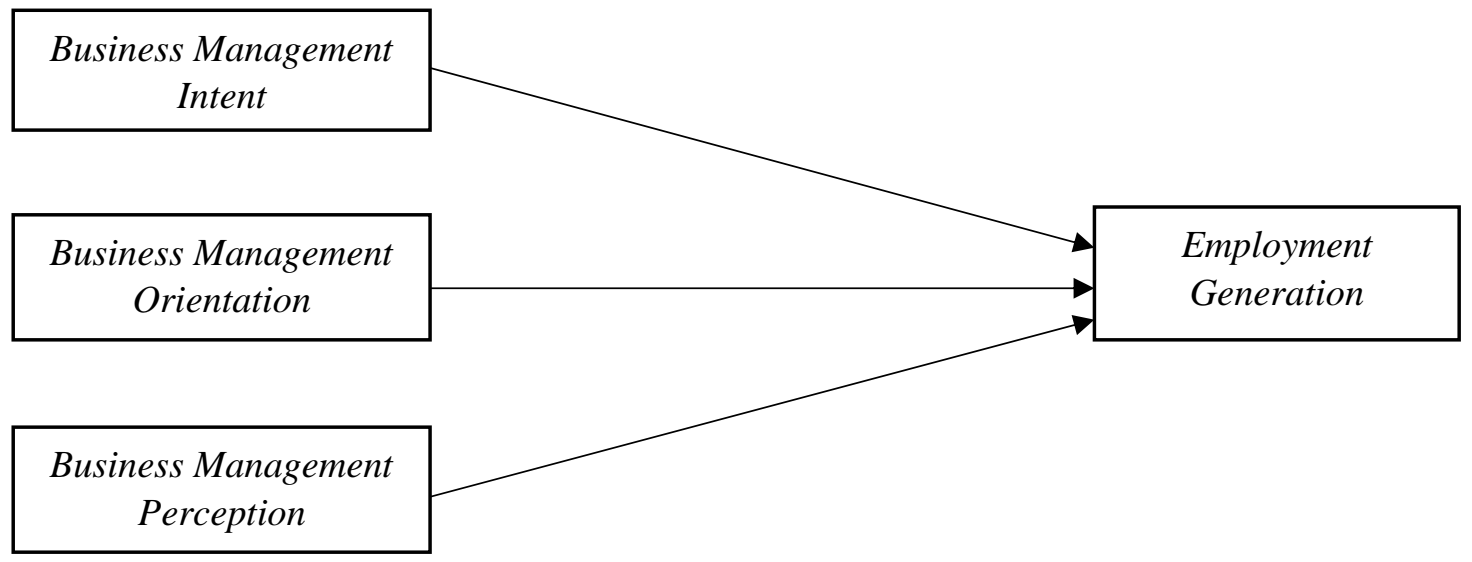

Figure: Framework

\section{Materials and Methods}

This study adopted quantitative research approach. The study also adopts cross-section research design in which data were collected once during the whole study. This research work adopted the questionnaire (primary source). The questionnaire was designed through selfadministered with the primary aim of eliciting relevant information pertaining to the problem of the study. It was considered as an efficient and appropriate data collection method, because information has been designed to avoid biases. The study adopted seven (7) point Likert scale ( 1 = Strongly disagree; 2 = Disagree; 3 = Fairly disagree 4 = Neutral; 5 Fairly agree $6=$ Agree; 7 = Strongly agree) . 
The target population of the study was an individual graduate who is in the NYSC orientation camp kubwa. The target population for this study was approximately 3,870 of the National Youth Service Corp (NYSC) (NYSC, 2021). The unit of analysis in this study were individual.The sample size is 363 using Taro Yamani (1967) formulae. The study also, adopted Stratified Random Sampling Technique.In the analysis of data, this study analyzed data using both correlation and regression analysis using Statistical Package for Social Science (SPSS) computer software 22.The data were then analyzed and interpreted statistically, while drawing conclusions or making inferences about the population of the study at one point in time.

\section{Analysis and Results}

From response rate, 363 copies of questionnaire distributed, only 321 were returned while 42 were not returned. Of these 321 copies of questionnaire returned, 11 were not used because they were invalid. Therefore, only 310 copies of questionnaire returned are used for the analysis, which representing an effective response rate of $91 \%$ in this study.

Table 1: Result of Test of Hypothesis One

\begin{tabular}{|c|c|c|c|c|c|}
\hline & \multicolumn{5}{|l|}{ Coef } \\
\hline \multirow[b]{2}{*}{ Model } & \multicolumn{2}{|c|}{ Unstandardized Coefficients } & \multirow{2}{*}{$\begin{array}{l}\text { Standardized } \\
\text { Coefficients } \\
\text { Beta }\end{array}$} & \multirow[b]{2}{*}{ T } & \multirow[b]{2}{*}{ Sig. } \\
\hline & B & Std. Error & & & \\
\hline \multirow[b]{2}{*}{$\begin{array}{l}\text { 1.(Constant) } \\
\text { managerial } \\
\text { intent }\end{array}$} & 1.565 & 0.318 & & 8.412 & 0.000 \\
\hline & 1.542 & 0.054 & 0.347 & 5.977 & 0.035 \\
\hline
\end{tabular}

a. Dependent Variable: Employment Generation

R-square: 0.89

Table 2: Result of Test of Hypothesis Two

\begin{tabular}{|c|c|c|c|c|c|}
\hline & \multicolumn{5}{|c|}{ ients } \\
\hline \multirow[b]{2}{*}{ Model } & \multicolumn{2}{|c|}{ Unstandardized Coefficients } & \multirow{2}{*}{$\begin{array}{l}\text { Standardized } \\
\text { Coefficients } \\
\text { Beta }\end{array}$} & \multirow[b]{2}{*}{$\mathrm{t}$} & \multirow[b]{2}{*}{ Sig. } \\
\hline & $\mathrm{B}$ & Std. Error & & & \\
\hline \multirow[b]{2}{*}{$\begin{array}{l}\text { 1.(Constant) } \\
\text { managerial } \\
\text { orientation }\end{array}$} & 0.132 & 0.312 & & 16.232 & 0.000 \\
\hline & 0.132 & 0.224 & 0.501 & 9.529 & 0.000 \\
\hline
\end{tabular}

a. Dependent Variable: Employment Generation

R-square: 0.79

Table 3: Result of Test of Hypothesis three

Coefficients

\begin{tabular}{|l|l|l|l|}
\hline Model & Unstandardized Coefficients & $\begin{array}{l}\text { Standardized } \\
\text { Coefficients }\end{array}$ & $\mathrm{t}$ \\
\cline { 1 - 4 }
\end{tabular}




\begin{tabular}{|c|c|c|c|c|c|}
\hline & B & Std. Error & Beta & & Sig. \\
\hline \multirow{2}{*}{$\begin{array}{l}\text { 1. (Constant) } \\
\text { businesses } \\
\text { management } \\
\text { perception }\end{array}$} & 0.616 & 0.018 & & 9.421 & 0.000 \\
\hline & 5.323 & 0.619 & 0.398 & 7.134 & 0.000 \\
\hline
\end{tabular}

a. Dependent Variable: Employment Generation

R-square: 0.72

Table 4: Means and Standard Deviation

\begin{tabular}{llll}
\hline Variables & Mean & Std Deviation & Decision \\
\hline managerial Orientation & 3.90 & 0.56 & Supported \\
businesses management Perception & 4.33 & 0.47 & Supported \\
Managerial Intent & 2.60 & 0.61 & Supported \\
Employment Generation & 3.64 & 0.45 & Supported \\
\hline
\end{tabular}

Source: SPSS Software (Version 22), 2021

\section{Discussion and Recommendations}

Going by the results of the hypotheses formulated and analyzed, in the hypothesis one, as stated that there is a positive influence of business managerial intent on employment generation in Abuja. The above Table 1 supported this hypothesis. The result in Table 1 above, shows a statistically significant relationship between managerial intent and employment generation in Abuja with .347 beta and t-value of 5.977 at $p<0.001$ significant levels. This finding is consistent with the previous studies (Nuhu et al. 2018; Haines et al., 2013).

This hypothesis stated that there is a positive influence of managerial orientation onemployment generation. The above Table 2 supported this hypothesis. The result shows a strength, influence with a beta value of .501 , and $t$ - value of 9.529 at $p<0.05$. This result shows clearly that business management orientation is a strong predictor of employment generation. Therefore, it can be asserted that the higher the managerial orientation on the individual, the higher to employment generation. The above result is in line with the work of Nuhu et al. (2018); Haines et al, (2013).

The final and third hypothesis of this study stated that, there is a positive influence of business managerial perception onemployment generation. From the above Table 3, the result also shows a positive influence of business management perception onemployment generation with the beta of .398 and $t$-value of 7.134 at $p<0.005$ significance level. The result supported the hypothesis which interred that the better perception on business management the better the influence on employment generation. This outcome was in line with the finding of Kropp, Lindsay and Shoham (2008) who conducted a research on managerial intent and international business venture start up in South Africa.

This study has recommended that managerial practices in Abuja should provide more training and development programs for entrepreneurs. The training should focus on developing and nurturing the graduates across the country. Hence, improve support and assistance from the 
government and financial institutions would definitely help these enterprises fully engage in innovation and other proactive activities and thus allow them to venture into risky territory with a high potential for profits. Financial support from the government and financial institutions seems to be very important for the organizational performance of managerial graduates. This study suggested the future researchers should either adopt or adapt the use of a moderator and mediated. More also, using new methodological changes and new theoretical approaches.

\section{Contribution to Knowledge}

The study contributed toward understanding the influence of business management practices on employment generation in Abuja. The result of this research was in line with the previous theoretical framework and supported by literatures. Theory of planned behavior considered as a leading theory in predicting individual behavior due to its robust and validity. A theory of planned behaviors is a means that nurtured understanding entrepreneurial venture creation process by nurturing attitudes and perceptions towards the behavior.

In determining behaviors that lead to the creation of new businesses, theory of planned behavior is very explainable in these phenomena. In a nutshell perceived behavioral control has a direct connection with self-perception, this might have a significant relationship to this study. The study found that business management practices was significantly influenced on employment generation. Thus, the study supports the importance of the business management practices via managerial Intent, orientation and perception on the employment generation. The study empirical results are consistent with the conceptual and theoretical framework of the study. The results highlight the evidence of theory of planned behavior (Ajzen, 1991; Shapero's, 1982) and elucidate on the influence of the underpinning theory. In so doing, the gap between the behaviors of business management practices (managerial Intent, orientation and perception) on employment generation were filled based on the theory. In a nutshell, business management practices behavioral control has a direct connection with employment generation.

The study has contributed significantly to the existing knowledge, especially in context of Nigeria. Policy makers at various levels could enhance policies that would encourage business management (managerial Intent, orientation and perception) activities among students, youths potential business owners through skills acquisition centers and providing training that could improve business management thinking. Governments at all levels (Federal and State) should put in place policies that could enhance livelihood of their teaming youths to reduce relying on the governments and avoid redundancy among the youth after their graduation. The government should encourage small and medium business enterprises among the graduates through collaboration with financial institutions on public private partnership policy. This will improve the standard of living and reduced or eliminate unemployment among the graduates. Furthermore, criminal acts such as robbery, banditry, kidnapping, raping, drug abuse, etc. could also reduce drastically among the youths.

From the findings of this study, the Universities authority could benefit from this research by addressing or incorporating the teaching of business management (managerial Intent, orientation and perception) practices and putting in place all necessary input that should 
enhance students mind set and curriculum that would involve business management (managerial Intent, orientation and perception) courses in each program regardless of the student's area of specialization. The present study could also benefit universities from creation centers' that were carried out all business activities in the university. Centre for business management development should design extra curriculum activities that may encourage clubs in campus that are responsible for promoting business management activities. This could be done by encouraging exhibitions, inter house (DPP) business competition, retreat program, collaborative training with other institutions and by inviting successful businesses to deliver a speech to share practical experiences etc.

\section{Reference}

Abisuga-Oyekunle, O. A., Patra, S. K., \&Muchie, M. (2020). SMEs in sustainable development: Their role in poverty reduction and employment generation in sub-Saharan Africa. African Journal of Science, Technology, Innovation and Development, 12(4), 405-419.

Aburumman, O., Salleh, A., Omar, K., \& Abadi, M. (2020). The impact of human resource management practices and career satisfaction on employee's turnover intention. Management Science Letters, 10(3), 641-652.

Acs, Z., \&Storey, D. (2014). Introduction, Entrepreneurship development and Economic Development. Regional Studies, 38(8), 871-877.

Arogundade, B.B. (2011). Businesses management Education: An Imperative for Sustainable Development in Nigeria, Journal of Emerging Trends in Educational Research and Policy Studies (JETERAPS). Vol.2 No.1: Pp 26-29.

Arshad, A. S., Rasli, A., Arshad, A. A., \& Zain, Z. M. (2014). The impact of managerial orientation on business performance: A study of technology-based SMEs in Malaysia. Procediasocial and behavioral sciences, 130, 46-53.

Audretsch, D.,\& Fritsch, M. (2007). The geography of firm births in Germany. Regional Studies, 28(4), 359-365.

Ayoade, E. O., \&Agwu, P. E. (2016). Employment generation through managerial development: The Nigerian experience. British Journal of Economics, Management \& Trade, 11(3), 1-14.

Baron, R. A.,\& Shane, S. C. (2015). Entrepreneurship development, a process perspective, Thomson South Western, Mason, OH (2005).

Baumol, W. (2014). Entrepreneurship development in economic theory. American Economic Review Papers and Proceedings, pp. 64-71.

Bird, T. D. (2019). Hereditary ataxia overview. GeneReviews ${ }^{\circledR}$ [internet].

Carree, M. A., \&Thurik, A. R.(2013). The Impact of Entrepreneurship development on Economic Growth. International Handbook of Businesses management Research, edited by ZoltanAcs and David Audretsch

Davidsson, P., Lindmark, L.,\&Olofsson, C. (2013). Entrepreneurship and economic development: The role of small firm formation and expansion for regional economic wellbeing. Journal of Enterprising Culture, 1, 347-366

Haines, H. M., Hildingsson, I., Pallant, J. F., \&Rubertsson, C. (2013). The role of women's attitudinal profiles in satisfaction with the quality of their antenatal and intrapartum care. Journal of Obstetric, Gynecologic \& Neonatal Nursing, 42(4), 428-441. 
Israel, K. J., \&Johnmark, D. R. (2014). Managerial mind-set among female university students: A study of University of Jos Students, Nigeria. Chinese Business Review, 13(5).

James, J. D., Delia, E. B., \&Wann, D. L. (2019). No" is not "low": Improving the assessment of sport team identification. Sport Marketing Quarterly, 28(1), 34-45.

Khalil, M., Khalil, R., \& Khan, S. (2019). A study on the effect of supply chain management practices on organizational performance with the mediating role of innovation in SMEs. Uncertain Supply Chain Management, 7(2), 179-190.

Kirchhoff, B. A., \& Phillips, B. D. (1988). The effect of firm formation and growth on job creation in the United States. Journal of Business Venturing, 3(4), 261-272

Kropp, F., Lindsay, N. J., \&Shoham, A. (2008). Managerial orientation and international managerial business venture startup. International Journal of Managerial Behavior \& Research.

Krueger, J. I. (2008). From social projection to social behaviour. European review of social psychology, 18(1), 1-35.

Lawal', B., \& Nuhu, M. Board Diversity or Tokenism: A Case for Social Inclusion and an Efficiency Model.

Lumpkin, G. T.,\&Dess, G. G. (2013). Clarifying the managerial orientation construct and linking it to performance. Academy of Management Review 21(1), 135-172

Matanmi, S., and Awodun, M. (2015). An Assessment of Competitive Strategies and Growth Patterns of New Enterprises in Nigeria using the Developing Economy Model. Lagos Organization Review, Volume 1, No. 1, June - August: 26-32.

Nkechi, A., Ikechukwu, E. J., \&Okechukwu, U. F. (2012). Entrepreneurship development and employment generation in Nigeria: Problems and prospects. Universal Journal of Education and General Studies, 1(4), 88-102.

Nuhu, M., \& Ahmad, B. S. (2017). Board composition and performance of listed firms in Nigeria: mediated and moderated model. Academic Journal of Business and Retail Management Research, 3(11), 25-38

Nuhu, M., \& Ahmad, B. S. (2017). Does corporate governance matter? Issues and challenges of the code of best practice in Nigerian. Academic Journal of Business and Retail Management Research, 3(11), 116-123

Nuhu, M., \&Hussani, S. M. (2017). Empirical study of the relationship between board of director mechanisms and perceived performance of listed firms in Nigeria. Journal of Accounting and Finance in Emerging Economies, 3(2), 159-178.

Nuhu, M., Rogo, H. B., \& Mohammed, U. D. (2018). Investigating the Influence of Shareholder Mechanisms on the Perceived Performance of Listed Firms in Nigeria. Review of Economics and Development Studies, 4(1), 79-89.

Ogundele, O. J. K., Akingbade, W. A., \&Akinlabi, H. B. (2017). Entrepreneurship training and education as strategic tools for poverty alleviation in Nigeria. American International Journal of Contemporary Research, 2(1), 148-156.

Ogundele, O.J.K., and Olayemi, O.O. (2004); Managerial Education and Social Economic Reconstruction; Nigeria Journal of Curriculum and Institution, Vol. 12, No. 1, September

Osabohien, R., Matthew, O., Gershon, O., Ogunbiyi, T., \& Nwosu, E. (2019). Agriculture development, employment generation and poverty reduction in West Africa. The Open Agriculture Journal, 13(1). 
Osuagwu, L. (2008) Entrepreneurship development in a Developing Economy; Empirical evidence from Nigeria Business Organizations; International Journal of Entrepreneurship, Vol.6, Pp: 19-32

Osuagwu, L (2012) Entrepreneurship development in a Developing Economy; Empirical evidence from Nigeria Business Organizations; International Journal of Businesses management, Vol.6, Pp: 19-32.

Sánchez, J. C. (2013). The impact of an Entrepreneurship development education program on managerial competencies and intention. Journal of small Entrepreneurship development, 51(3), 447-465.

Searle, K. A., Litts, B. K., \& Kafai, Y. B. (2018). Debugging open-ended designs: High school students' perceptions of failure and success in an electronic textiles design activity. Thinking Skills and Creativity, 30, 125-134.

Shapero, A., \& Sokol, L. (1982). The social dimensions of Entrepreneurship developmenta. University of Illinois at Urbana-Champaign's Academy for Managerial aLeadership Historical Research Reference in Businesses management.

Teixeira, A. A., \& Davey, T. (2010). Attitudes of Higher Education students to new venture creation: a preliminary approach to the Portuguese case. Industry and Higher Education, 24(5), 323-341.

Van Stel, A., Carree, M, \&Thurik, R. (2015). The effect of managerial activity on national economic growth. Small Business Economics, 24(3), 311-321

Widiger, T. A., Sellbom, M., Chmielewski, M., Clark, L. A., DeYoung, C. G., Kotov, R., ...\& Wright, A. G. (2019). Personality in a hierarchical model of psychopathology. Clinical Psychological Science, 7(1), 77-92.

Yamane, T. (1967). Elementary sampling theory.

Younas, M., \& Bari, M. W. (2020). The relationship between talent management practices and retention of generation ' $Y$ 'employees: mediating role of competency development. Economic Research-Ekonomskalstraživanja, 33(1), 1330-1353.

Zaid, A. A., Jaaron, A. A., \& Bon, A. T. (2018). The impact of green human resource management and green supply chain management practices on sustainable performance: An empirical study. Journal of cleaner production, 204, 965-979. 